\title{
OSACZENI PRZEZ VOLKSGEMEINSCHAFT. POLSKO-NIEMIECKA RELACJA O MIŁOŚCI I OSAMOTNIENIU W III RZESZY
}

Für Christa Schulze in Dankbarkeit

Jednym z najbardziej znaczących źródeł do historii narodowego socjalizmu stały się pamiętniki Józefa Goebbelsa, których pełną edycję, obejmującą trzydzieści dwa tomy, zakończono w roku 20061. Śledząc zapiski autora, zauważamy, że wraz z postępującą popularnością nazistowskiej partii $\mathrm{w}$ różnych miejscach Niemiec, rosła także samoświadomość piszącego, który od lat trzydziestych zabiegał o względy przywódcy nazistów i kreował siebie na jednego z głównych współpracowników Adolfa Hitlera. Ruch hitlerowski wyrósł na resztkach założonej przez Antona Drexlera i Karla Harrera w roku 1919 Niemieckiej Partii Robotniczej (DAP), sytuującej się po prawej stronie układu, który spotkamy przez cały okres trwania Republiki Weimarskiej - była to z jednej strony radykalna prawica obejmująca grupy antydemokratyczne, volkistowskie i antysemickie, a z drugiej strony socjaldemokraci, katolickie centrum oraz liberałowie wspierający kruchą demokrację. Uformowany $\mathrm{w}$ latach dwudziestych, jako partia polityczna, nazizm forsowany i instrumentalizowany był przez wielki kapitał przemysłowy posiadaczy ziemskich, sprzyjających siłom negującym demokrację. Od początku lat trzydziestych NSDAP stała się jedną z głównych sił poli-

${ }^{1}$ Por. Die Tagebücher von Joseph Goebbels, Hrsg. von E. Fröhlich, München 1993-2006. 
tycznych, z którą w Niemczech liczyli się wszyscy². Powołanie Adolfa Hitlera na kanclerza Rzeszy Niemieckiej w dniu 30 stycznia 1933 roku oznaczało dla polityków zmianę, której się nie spodziewali, choć stare elity liczyły na utemperowanie nazistów i oczekiwały spokojnego sprawowania rządów bądź trwania w koalicji3.

W latach 1930-1932 partia nazistowska współrządziła na poziomie lokalnym w Brunszwiku, Anhalcie, Meklenburgii i Oldeburgu. W Turyngii naziści sprawowali rządy większościowo, posługując się metodami, które dwa lata później stosować będą na terenach całych Niemiec - ze stanowisk w policji i szkolnictwie usuwano reprezentantów socjaldemokracji, a urzędnicy o jakimkolwiek cieniu podejrzenia o relacje osobiste z Żydami byli szykanowani i także pozbawiani urzędów. Na uniwersytecie w Jenie powołano w 1932 r. pierwszego wykładowcę nauki o rasach, reprezentującego poglądy nazistowskie, a na wykładzie inauguracyjnym Hitler pojawił się osobiście4.

Führer i jego współpracownicy obiecywali, że wraz z nadejściem ich rządów naród będzie w stanie się zjednoczyć, a waśnie partyjne ucichną. Już pierwsze miesiące nowej władzy ukazały, że instrumentem pierwszej potrzeby będzie zastraszanie i terror, a centralnym hasłem, forsowanym przez następne, lata będzie volksgemeinschaft, czyli wspólnota narodowa, której kształt i formowanie zajmuje pokaźną część notatek pamiętnikarskich Josepha Goebbelsa.

Wspólnota narodowa, jaką zamierzali kreować naziści, miała wynikać z jedności łączącej jednostkę z narodem (Ty jesteś niczym, twój naród wszystkim), zespalającej się z nim więzami krwi i wspólnego losu. Takie rozumienie wspólnoty włączono w 1934 roku do stosowanych w nauczaniu szkolnym podręczników nowego przedmiotu, określanego mianem „higieny rasowej”:

Niemiecka krew, która przez wieki stała się ogromnym strumieniem, łączy nas wszystkich w jedną dziedziczną całość [Erbmasse]. Nikt od niej nie może uciec, nawet jeśli wyemigruje bądź zamieszka wśród obcych ludów. W tej masie, którą dziedziczymy, zawiera się jądro określające naszą istotę i jest ono niezbywalne ${ }^{5}$.

Indywidualne zjednoczenie ze zbiorowością przenoszono także na relacje międzyludzkie z zamiarem stworzenia rozumianej biologicznie struktury

2 Pamiętniki Goebbelsa ukazują nam dokładnie jego drogę do tej partii, notatki z lat 19241925 dostępne są od 2004 roku. Por. tom 25, październik 1924 r..

${ }^{3}$ R.J. Evans, Das Dritte Reich, Aufstieg, München 2004.

${ }_{4}^{4}$ R.Hosferld, H. Pölking, Die Deutschem 1918 bis 1945. Leben zwischen Revolution und Katastrophe, München 2006, s. 207-208.

${ }^{5}$ Jeśli nie zaznaczono inaczej, wszystkie tłumaczenia pochodzą od autorki artykułu; cyt. za: J. Graf, Vererbungslehre, Rassenkunde und Gesundheitspflege, Berlin 1939, s. 159. 
społecznej. W obrębie narodowosocjalistycznej ideologii, realizacji takich zamierzeń mógł się podjąć tylko dynamiczny i sięgający po najradykalniejsze środki ruch polityczno-społeczny, za który naziści uważali siebie samych. Gwarancją takich przemian stawał się system wodzowski' ${ }^{6}$. Utopijne hasło wspólnoty społecznej naziści wykorzystywali w celu włączenia do swych działań środowisk robotniczych, które dystansowały się od nazistów. Dzień 1 maja 1933 ogłoszono świętem państwowym, serwowano przysłowiowe piwo i kiełbasę, aby na następny dzień siłą likwidować związki zawodowe7 . Droga do nazistowskiej wspólnoty narodowej wiodła przez proces podporządkowywania się organizacji, stowarzyszeń itd., jednemu kierownictwu i tworzonymi przez rządzącą NSDAP strukturom nadrzędnym. Zniknęły opozycyjne partie polityczne (bądź zeszły do podziemia), związki zawodowe zgrupowano w Niemieckim Froncie Pracy (Deutsche Arbeitsfront). Wartością bardzo wysoko cenioną przez nazistów była ziemia uprawna, a rolnicy, jako przedstawiciele warstwy społecznej istotowo, mitycznie wręcz związanej z osadnictwem od pradawnych, germańskich czasów, cieszyli się szczególnymi względami. Ministrem rolnictwa Rzeszy został R. Walther Darrè, który stwierdził, że efektem zmian społecznych przeprowadzanych $\mathrm{w}$ ramach wspólnoty będą narodziny nowej klasy społecznej - nowej szlachty - wyrosłej na połączeniu krwi i ziemi (Blut und Bo$d e n)^{8}$. Gospodarka w nazistowskich Niemczech została wprzęgnięta w całość systemu i czerpała profity z norm prawnych nakierowanych na wyłączenie niektórych podmiotów i całych grup społecznych ${ }^{9}$. Podobnym mechanizmom poddano sferę kultury, nauki i sztuki - skonsolidowanie całego obiegu kultury przyczyniło się do wzmocnienia kontroli państwa nad społeczeństwem $\mathrm{w}$ sposób niewyobrażalnie głęboki ${ }^{10}$. Jednym $\mathrm{z}$ niewielu obszarów, które hitlerowskiemu systemowi sprawiało ogromne kłopoty w tworzeniu organizmu wspólnotowego, była szeroko rozumiana religia, szczególnie zaś chrześcijaństwo ${ }^{11}$.

6 K. Pätzold, M. Weißbecker, Die Geschichte der NSDAP 1920 bis 1945, Köln 2009.

7 E. Piper, Nationalsozialismus, Seine Geschichte vom 1919 bis heute, Münster - Berlin 2012, s. 111-112.

${ }^{8}$ K. Bauer, Nationalsozialismus, Wien - Köln - Weimar 2008, s. 272.

${ }^{9}$ A. Tooze, Ökonomie der Zerstörung. Geschichte der Wirtschaft im Nationalsozialismus, München 2007.

10 P. Longerich, J.Goebbels, Biographie, München 2010, s. 329-363.

${ }^{11}$ Por. np. materiały źródłowe zawarte w tomie: Herausgefordert. Dokumente zur Geschichte der Evangelischen Kirche in der Zeit des Nationalsozialismus, Hrsg. von S. Hermle, J. Thierfelder, Stuttgart 2008. 
Jednym z najistotniejszych elementów od nowa „zdefiniowanej” struktury stał się system prawny nazistowskich Niemiec, bez którego nie udałoby się takich planów konsekwentnie realizować ${ }^{12}$.

Najważniejszym warunkiem „przemodelowania” społecznego i narodowosocjalistycznej inżynierii społecznej było kryterium rasy, rozumianej ontologicznie. Rasa była elementem, decydującym o „być albo nie być" jednostki ludzkiej. Ustawodawstwo nazistowskie, narzucając kryteria przyporządkowania do jedynie akceptowalnej rasy "aryjskiej”, przewidywało cały system zakazów i nakazów eliminujących z organicznie pojętej wspólnoty tych, którzy owych kryteriów nie spełnili. Przepisy, skierowane na początku głównie do ludności pochodzenia żydowskiego's, zaczęto rozszerzać także na inne grupy (dobierane arbitralnie, np. homoseksualistów, przeciwników politycznych, duchowieństwo itd.).

Podążając za rozpoznaniami Mechtild Brand, znakomitej badaczki życia codziennego w nazistowskich Niemczech, warto zauważyć, że Trzecia Rzesza realizowała się w relacjach międzyludzkich, "u dołu”, w sąsiedztwie, a sukces nazistowskich zamierzeń zależał w znacznej mierze od konkretnej realizacji dyrektyw władzy aż do poziomu rodziny nuklearnej włącznie.

Rzeczywistość należy badać, analizować i opisywać ${ }^{4}$ przede wszystkim w skali mikro, a obraz hitlerowskiego państwa postrzegany z niemieckiej prowincji, z dala od zgiełku takich metropolii, jak Monachium, Berlin czy Hamburg, uzupełnia naszą wiedzę o funkcjonowaniu dyktatury w kategoriach regionalnych, tak bardzo typowych dla kultury i historii Niemiec sensu largo. Niektórzy historycy są zdania, że historii nazizmu nie napisze się do końca nigdy, gdyż należy przebadać i opisać każdy kawałek ziemi, który był częścią hitlerowskiego państwa i którym rządzili hitlerowscy urzędnicy ${ }^{15}$.

Próbą generalną dla wspólnoty narodowej stała się wywołana przez III Rzeszę wojna i jej przebieg, wiążący Rzeszę z terenami okupowanymi

12 L. Poliakov, J. Wulf, Das Dritte Reich und seine Denker, Wiesbaden 1989, s. 334.

13 Proces wykluczania Żydów niemieckich z Volksgemeinschaft do 1942 r. opisuję w artykule: Pole eksperymentalne Warthegau. Glosy do pewnych wypowiedzi Edyty Stein, "Zeszyty Naukowe Centrum Badań im. Edyty Stein” 11 (2014) „Fenomen Edyty Stein - Das Phänomen Edith Stein", red. M. Bernhardt, A. Grzegorczyk, M. Grzywacz, K. Machtyl, s. 185-197. Na pograniczu ustaw rasowych w Niemczech znajdowali się tak zwani mieszańcy (czyli Mischlinge,) pierwszego, bądź drugiego stopnia, jeśli któryś z rodziców był pochodzenia "aryjskiego". Kategorii tej nie stosowano nigdzie indziej poza Niemcami. Osoby te dołączyły ostatecznie do większości ofiar Shoah. Jeśli przeżyły, to nie przyznawały się do swego pochodzenia. Por. J.Tent, In the Shadow of the Holocaust. Nazi Persecution of Jewish-Christian Germans, Westbrooke 2003.

14 Por. M. Brand, Unsere Nachbarn. Zigeuner, Sinti und Roma, Lebensbedingungen einer Minderheit in Hamm, Essen 2007.

${ }^{15}$ F. Bajohr, M. Wildt: Volksgemeinschaft. Neue Forschungen zur Gesellschaft des Nationalsozialismus, Frankfurt a.M. 2009, wstęp. 
w prawie wszystkich dziedzinach życia. Mark Mazower określił nazistowskie Niemcy mianem „imperium nowego porządku”, które w Europie czerpało z zasobów wszystkich podbitych narodów i tyko kwestią czasu miało być utrwalenie tego systemu na dyktowanych przez nazistów warunkach, których koncepcje teoretyczne wypracowywali identyfikujący się z systemem naukowcy ${ }^{16}$, wprzęgając $w$ takie działania całe dyscypliny wiedzy - od archeologii poczynając ${ }^{17}$, a na kwestiach gospodarczych kończąc ${ }^{18}$.

\section{Mikrokosmos na pograniczu niemiecko-szwajcarskim - miasteczko Lörrach i jego droga do Volksgemeinschaft}

Położone $\mathrm{w}$ Badenii19 ${ }^{19}$ Lörrach liczy obecnie niespełna pięćdziesiąt tysięcy mieszkańców i jest siedzibą powiatu graniczącego bezpośrednio z gminą Riehen, należącego do szwajcarskiego kantonu Basel-Land. Niedaleko jest stamtąd także do francuskiej Alzacji. Dzisiejszą rzeczywistość tamtych terenów możemy określić mianem udanej realizacji koncepcji euroregionów, łączących Niemcy z Francją i niezrzeszoną w Unii Europejskiej Konfederacją Szwajcarską ${ }^{20}$.

W okresie międzywojennym sytuacja Badenii była zgoła odmienna - jej przygraniczne położenie wciąż przypominało o działaniach znienawidzonej Francji, która po zakończeniu Wielkiej Wojny w roku 1918 stosowała wszystkie drakońskie środki, jakie przewidywał układ z Saint Germain ${ }^{21}$ : od kontrybucji wojennych, przez reparacje surowcowe, po likwidację siły militarnej Niemiec.

16 Wystarczy przypomnieć tu założenia i częściową realizację zbrodniczego zamysłu określanego Generalnym Planem Wschodnim (Generalplan-Ost) na terenach podbitego i okupowanego przez wojska niemieckie państwa polskiego. W jego przygotowanie zaangażowani byli profesorowie Uniwersytetu Berlińskiego. Por. B. Mącior-Majka, Generalny Plan Wschodni. Aspekty ideologiczny, polityczny i ekonomiczny, Kraków 2007.

17 Por. katalog wystawy, która miała miejsce w Focke-Museum (Brema): Graben für Germanien,. Archäologie umterm Hakenkreuz, hrsg. von Focke-Museum unter Mitarbeit von S. Geringer, F. von der Haar, Bremen 2013.

18 A. Tooze, op. cit., s. 127-129.

${ }^{19}$ Badenia, Baden, to kraina historyczna w południowo-zachodnich Niemczech, przynależąca od 1951 roku do kraju związkowego Badenia-Wirtembergia. W okresie Trzeciej Rzeszy teren ten stanowił samodzielny kraj związkowy. Dane historyczne z: Leksykon PWN. Europa, Regiony i państwa historyczne, red. M. Kamler, Warszawa 2000, s. 33.

${ }^{20}$ Por. wwwdreilaendermuseum.eu/willkommen (dostęp: 5.06.2014 r.).

${ }^{21}$ Por. W. Künzel, W. Rollecke, Geschichte der deutschen Länder. Entwicklungen und Traditionen vom Mittelaler bis zur Gegenwart, Münster 2008, s. 52. 
Zakończenie działań wojennych w 1918 roku, zmiany terytorialne na zachodzie Rzeszy, odstąpienie Francji Alzacji i Lotaryngii oraz powrót żołnierzy frontowych przyczynił się do całkowitego załamania się sytuacji gospodarczej i tak nadwyrężonej trwającą wojną w Badenii. Lata dwudzieste to narastający klimat politycznej agresji, będący pożywką dla rozwoju komunistycznego terroryzmu, którego apogeum stanowił nieudany zamach na życie nadburmistrza Lörrach, dr. Erwina Gugelmeiera (1879-1945)22. Rozwój NSDAP na tym terenie przypada na lata 1930-1932, a ilość członków partii wzrosła $\mathrm{w}$ tym okresie $\mathrm{z}$ dziesięciu do trzystu ${ }^{23}$. W radzie miasta naziści byli reprezentowani od 1930 roku, a w wyborach do Reichstagu dnia 5 lipca 1932 roku zwolennicy Hitlera osiągnęli $34,5 \%$ poparcia, tworząc najsilniejszą partię polityczną $\mathrm{w}$ tych okolicach. Po przejęciu władzy $\mathrm{w}$ przyspieszonych wyborach (mających potwierdzić siłę polityczną NSDAP) ${ }^{24}$ naziści zastąpili istniejące rządy w krajach związkowych, powołując namiestników Rzeszy (Reichsstatthalter). Był to pierwszy krok w stronę unifikacji administracyjnej państwa i zakwestionowania zasady federalizmu. W Lörrach przejęcie władzy nastąpiło w dwóch etapach: czołowy nazista, Reihnard Boos (18971979), został mianowany $z$ nadania NSDAP komisarzem administracyjnym miasta, a jednocześnie rozpoczęto kampanię zniesławiającą dotychczasową radę miejską, która pod płaszczykiem demokracji przyjęła kandydaturę R. Boosa jako jedyną "demokratyczną" (sic!), i przekazano w ten sposób kontrolę nad miasteczkiem wyłącznie nazistom. Od dziesiątego marca do połowy lipca 1933 roku nastąpiło całkowite włączenie istniejących do tej pory związków i stowarzyszeń do nazistowskich przybudówek: administracja miejska była całkowicie $\mathrm{w}$ rękach zwolenników hitlerowskiego, nawet dyrektorzy banków i kas oszczędnościowych byli mianowani z poparcia NSDA $^{25}$. Lokalna sytuacja przygraniczna prowadziła także do coraz silniejszego odcięcia tych terytoriów od kontaktów zewnętrznych, tak że w roku 1938 ruch transgraniczny praktycznie zanikł. Podobnie było na innych rubieżach niemieckiego państwa: niektóre tereny przygraniczne były od polowy lat dwudziestych XX wieku utrzymywane w stanie permanentnego zagrożenia, które niemiecka polityka w okresie Republiki Weimarskiej w znacznej mierze kreowała, a naziści jeszcze spotęgowali26.

22 Por. Lörrach und der Nationalsozialismus, "Lörracher Hefte 18”, hrsg. von M. Moehring und A. Lauble, Lörrach 2013, s. 12.

23 W. Göckel, Lörrach im Dritten Reich, Schopfheim 1990, s. 16.

24 J. Evans, op. cit., s. 607.

${ }^{25}$ W. Göckel, op. cit., s. 15.

${ }^{26}$ Wschodnie pogranicze Niemiec, zmienione diametralnie $\mathrm{w}$ wyniku restytucji $\mathrm{w}$ ramach porządku powersalskiego Rzeczpospolitej Polski, określano często „krwawiącą” (blutende) granicą, mentalnie zdominowaną przez bardzo silny ładunek agresji i nacjonalizmu; por. J. Wąsicki, Prowincja Grenzmark Posen-Westpreußen 1918-1933, Zielona Góra 1967, s. 41. 
Lörrach, to niewielkie miasto powiatowe, miało się stać, zdaniem miejscowych nazistów, wzorcowym przykładem realizacji „volkistowskiej wizji germańskiej kultury" 27 i stanowić odpowiednią alternatywę dla kosmopolitycznej Bazylei. Rozpoczęto nawet budowę wielkiego placu paradnego, lecz nie ukończono jej z powodu wybuchu wojny.

W 1937 roku tak sytuację w Lörrach i okolicy podsumował urzędujący jako burmistrz i starosta powiatowy Boos: „Nie ulega wątpliwości, że cały naród zjednoczył się z NSDAP i jej zawdzięcza tworzenie niebywałych warunków rozwoju na wszystkich polach działania. Także na przyszłość Führer zaplanował realizację celów, które naród wzmocnią i pozwolą mu zachować polityczną wolność"28. Wtórował mu Hermann Burte (1879-1960), mieszkaniec powiatu Lörrach i jeden z najbardziej znanych nazistowskich pisarzy, którego twórczość Adolf Hitler uznawał za niezbędną w kształtowaniu wspólnoty narodowej, publikując na łamach Oberbadisches Volksblatt - najstarszej gazety codziennej ukazującej się na tamtych terenach - wiersze i opowiadania wspierające działania propagandowe i indoktrynacyjne władzy ${ }^{29}$.

Głównym instrumentem „wspomagającym” budowę nowego społeczeństwa była tajna policja państwowa (Gestapo), zależna w znacznej mierze od donosicielstwa mieszkańców. Podobnie jak w innych miejscach Niemiec, często zdarzało się, że donosili na siebie członkowie rodzin; panowała atmosfera ciągłej ostrożności i nieufność.

I choć popularność nazistów wśród społeczeństwa małomiasteczkowego była dość wysoka, to do połowy lat trzydziestych pojawiały się sporadyczne akty sprzeciwu i braku akceptacji rządów NSDAP, głównie ze strony nielegalnej partii komunistycznej (KPD) i Kościoła katolickiego

Rasistowskie pryncypia funkcjonowania wspólnoty narodowej przeniknęły tu bardzo szybko - w 1935 roku oplakatowano całe miasto afiszami o następującej treści:

27 W. Göckel, op. cit., s. 16.

${ }^{28}$ Cyt. za: H. Noe, Hingeschaut - Steinen im Nationalsozialismus. Die gesellschaftlichen und politischen Verhältnisse in Steinen in den Jahren 1933-1945, Lörrach 2014, s. 117.

${ }^{29}$ Postać H. Burtego wymagałaby osobnego omówienia, lecz musimy tu z takiego zabiegu zrezygnować. Znaczenie Burtego dla pogranicza niemiecko-szwajcarskiego oraz jego twórczość pozostają we ścisłym związku z kształtowaniem się ideologii volkistowskiej w Badenii. Burte był jednym z 1041 twórców kultury uznanych przez nazistów w 1943 roku, na wniosek J. Goebbelsa i przy całkowitym poparciu Hitlera, za "obdarzonych przez Boga” (gottbegnadet), których talent i praca miały służyć całkowicie wspólnocie narodowej i jej przetrwaniu. Wszystkie osoby ujęte na tej liście (ludzie pióra, muzyki, sztuk plastycznych itd.) były zwolnione od powołania do służby wojskowej. Listę tę nieco zweryfikowano pod koniec wojny, zezwalając na włączenie twórców do oddziałów samoobrony (Volkssturmu), czyniono to jednak nader rzadko. 
Siła woli i moc czynu charakteryzują człowieka zdrowego na ciele i duszy. Oba elementy są źródłem jego osiągnięć. Złamani duchowo, którzy dają się rozpoznać po swoim zachowaniu, są słabi!

Bezpośrednie nawoływanie do obserwacji otoczenia i skupienia uwagi na osobach, które odstawały od stopniowo włączanych do funkcjonowania społeczeństwa nowych „norm”, miało służyć przygotowaniu akcji eutanazji osób niepełnosprawnych na ciele i umyśle. Na terenie Badenii przeprowadzano ją w sposób drakoński do 1941 roku, kierując ofiary do obozu Grafeneck, gdzie ginęły w komorach gazowych ${ }^{30}$.

Chorobliwy antysemityzm hitlerowskich rządów okazał całą swą moc także i tu. Pierwszego kwietnia 1933 roku oddziały SA splądrowały żydowskie sklepy. W samym mieście mieszkało sześćdziesiąt pięć rodzin żydowskich, które dostosowały się do nazistowskiego ustawodawstwa, nie rzucając się mieszkańcom nadmiernie w oczy. Kilka lat relatywnego spokoju skończyło się 9 listopada 1938 roku, kiedy to zniszczono całkowicie wnętrze synagogi w Lörrach W akcji tej brało udział wielu zwykłych obywateli, którzy z własnej woli wspomagali „uzasadnioną złość ludu” - jak mawiał J. Goebbels. Deportacja Żydów z Lörrach nastąpiła 22 października 1940 roku. Wywieziono ich do położonego na południu Francji obozu koncentracyjnego w Gurs utworzonego w 1939 roku na mocy porozumienia nazistów $\mathrm{z}$ rządem Vichy.

Wielu było zadowolonych z wygnania Żydów, niektórzy skorzystali na tym finansowo, gdyż nabywali prawie za bezcen likwidowane mienie, kupując wszystko - od przysłowiowej igły do wielkich nieruchomości.

\section{Element obcy w Volksgemeinschaft - robotnicy przymusowi}

Sytuację gospodarczą Niemiec wybuch wojny zmienił diametralnie. Powołani do wojska mężczyźni zostali zastąpieni siłą roboczą pochodzącą z krajów podbitych i okupowanych przez wojska nazistowskie. Pierwszymi jeńcami zatrudnionymi na obszarze południowo-zachodniej Badenii byli jeńcy francuscy. Władze uzasadniały ich przyjęcie przede wszystkim pozytywną sytuacją polityczną: „Paryż został zdobyty”31. Wkrótce do Francuzów dołączyli także jeńcy wojenni i przymusowi robotnicy z Polski.

${ }^{30}$ http:/ / www.gedenkstaette-grafeneck.de (dostęp: 6.06.2014 r.).

${ }^{31}$ Ibidem. 
Do właściwego opisu funkcjonującej wspólnoty narodowej okresu Trzeciej Rzeszy przynależy historia ludzi wykonujących przymusową i niewolniczą pracę na rzecz tego państwa ${ }^{32}$. W ciągu całej wojny pracowało $\mathrm{w}$ nazistowskich Niemczech około dwunastu milionów ludzi. W powiecie Lörrach, jak i innych miejscach południowej Badenii 33 , zatrudniano przede wszystkim Polaków, Francuzów, Rosjan, Ukraińców i Łotyszy. Umowę o pracę robotników przymusowych podpisywały jednostki Wermachtu z przedsiębiorcami prywatnymi, których zawsze reprezentowały władze lokalne (burmistrz lub starosta powiatowy). W treści określono dokładnie na przykład liczbę robotników na zakład pracy, czas pracy, pensje, które odprowadzano do obozu macierzystego (Stalag = Stammlager), i czas obowiązywania umowy ${ }^{34}$. Procedura przyjmowania robotników, których nazywano pracownikami cywilnymi bądź obcymi, została uszczegółowiona w ustawodawstwie wojennym. Należy ich sfotografować, spisać (po raz kolejny wszystkie dane). Do pracy robotnicy wychodzą zawsze w kolumnach. Gdyby ktoś się oddalił, należało, po bardzo krótkim zawołaniu, wykonać strzał. Instrukcje obowiązujące $w$ całej Rzeszy przewidywały wyżywienie niezbędne do zapewnienia sił do pracy. Największy nacisk kładziono na wyraźne oznaczenie robotników i oddzielenie ich od członków niemieckiej Volksgemeinschaft. Zabroniono się im uczestnictwa $\mathrm{w}$ nabożeństwach, czytania niemieckich gazet i niemieckiej literatury, głośnego śpiewania $w$ miejscach publicznych, jazdy na rowerze, osobistych kontaktów z Niemcami czy spożywania wspólnych posiłków ${ }^{35}$. Każdą bliższą relację należało obserwować, a tajna policja liczyła na współpracę także i w tej kwestii.

\section{Wyzwanie dla Volksgemeinschaft. Krótka historia miłości Pauliny Kropf i Stanisława Zasady}

Nikt nie potrafi przekazać atmosfery minionego czasu, która jest dla niego bardziej charakterystyczna i wiarygodna od faktów. I właściwie tylko atmosfera różni od siebie, sama nie posiadając siły przekonywania, w znacznym stopniu podobne do siebie fakty z różnych epok. Na przykład: cudzołóstwo z jeńcem wojennym, udowodnione

32 Por. dwujęzyczny katalog wystawy: Erinnerung bewahren. Sklaven und Zwangsarbeiter des Dritten Reiches aus Polen 1939-1945. Zachować pamięć. Praca przymusowa i niewolnicza obywateli polskich na rzecz Trzeciej Rzeszy w latach 1939-1945, Warszawa - Berlin 2009, wydany przez Fundację Polsko-Niemieckie Pojednanie.

33 Por. B. Boll: Zwangsarbeit in Baden 1939-1945, „Geschichte in Wissenschaft und Unterricht" 1992, nr 9, s. 532-537. 138-139.

${ }^{34}$ Najnowsze badania z tego zakresu znajdziemy w pracy: H. Noe, Hingeschaut, op. cit., s.

35 Archiwalia z Lörrach i Steinen omówione w: ibidem, s. 140. 
faktami także z innych stref i okresów, nie było podczas pierwszej wojny światowej karalne i jeśli je karano je później, to także fakty, a mianowicie ustawy hitlerowskich Niemiec, ogłosiły cudzołóstwo przestępstwem karanym śmiercią, wtedy to atmosfera państwa policyjnego mogła na tym tle porazić chorobą umysłową całą wieś i sąsiednie miasto powiatowe. I potrafiła beztroskich dotąd sąsiadów, leśniczego i drwala, i małorolnego chłopa doprowadzić do tego, by dla „narodowo-obcego” postawić szubienicę ${ }^{36}$.

Zimą 1940 roku do małej wsi Brombach nieopodal Lörrach przybywa transport polskich jeńców wojennych. Znajduje się wśród nich pochodzący z Łodzi dwudziestodwuletni mężczyzna - Stanisław Zasada. Jest wysokim, przystojnym blondynem i gdyby nie był Polakiem, mógłby zewnętrznie uchodzić za przedstawiciela rasy aryjskiej. Wielu Polaków pracowało wówczas u Niemców i cieszyli się dość dobrą opinią, choć, jak twierdzą badacze, sytuacja robotników i jeńców ze Wschodu była generalnie zła, gdyż nie byli Niemcom równi pod względem rasowym ${ }^{37}$.

Paulina Kropf jest zamężną, młodą kobietą prowadzącą sklep warzywny.

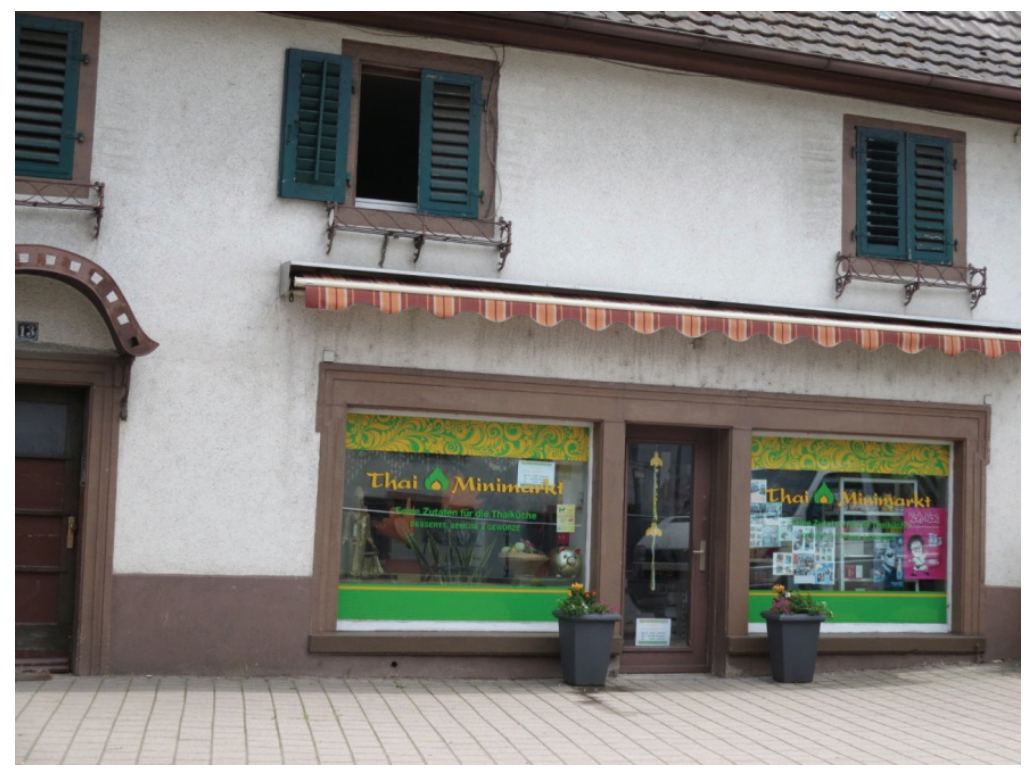

Rys. 1. Dawny sklep Pauliny Kropf (fot. Yves Jaenisch)

\footnotetext{
${ }^{36}$ R. Hochhuth, Miłość w Niemczech, tłum. E. Wachowiak, Poznań 1984, s. 50.

${ }^{37}$ Lörrach und der Nationalsozialismus, "Lörracher Hefte 18”, op. cit., s. 45.
} 
Stani, bądź Stasiek, jak go we wsi nazywają, pracuje obok, u młynarza, lecz czasem przychodzi do sklepu pomagać, gdyż Paulina nie daje sobie rady. Ma także dwoje dzieci. Raz na kilka miesięcy jej mąż, którego oddział stacjonuje we Francji, przysyła jej paczki. Młody Polak, mówiący nawet dość dobrze po niemiecku, zakochuje się $\mathrm{w}$ swej chlebodawczyni i między tym dwojgiem młodych ludzi rozwija się namiętność. Paulina Kropf i Stanisław Zasada spotykają się potajemnie przez kilka miesięcy. Jednakże w wiosce nic się nie ukryje. Paulina i Stanisław zostaną zadenuncjowani i muszą ponieść karę za skażenie germańskiej rasy.

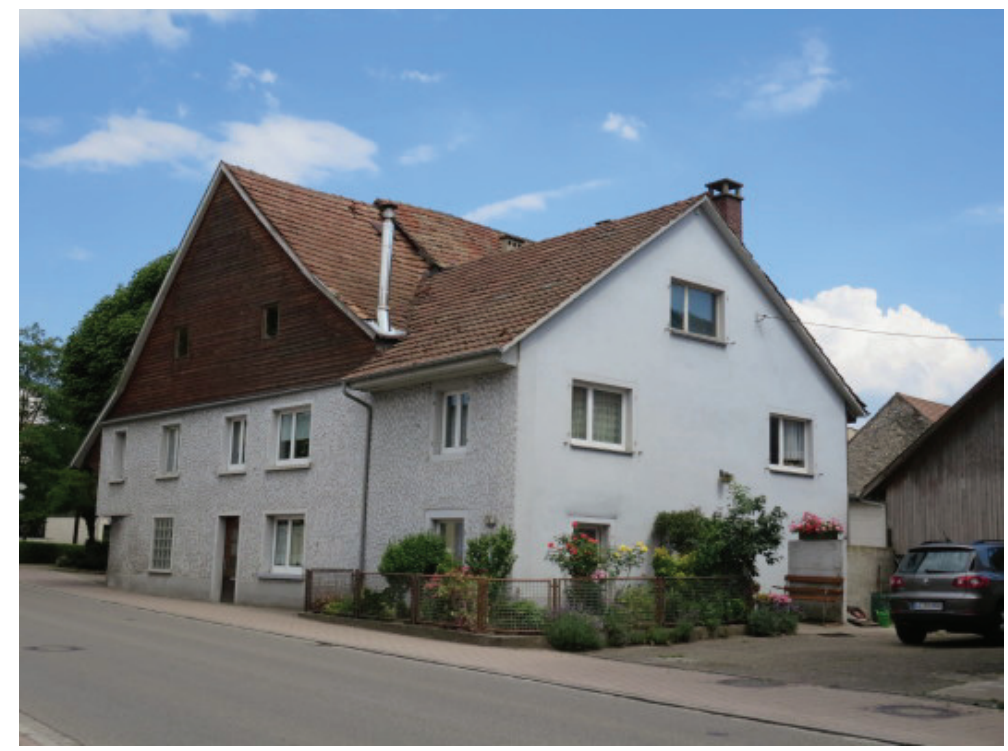

Rys. 2. Gospodarstwo, w którym pracował Stanisław Zasada (fot. Yves Jaenisch)

Nazistowskie prawo każde przewinienie robotnika przymusowego wobec niemieckiej kobiety, posiadającej udowodnione odpowiednimi zaświadczeniami pochodzenie aryjskie (to znaczy pozbawionej jakiejkolwiek „domieszki krwi żydowskiej"), traktowało jako przestępstwo najwyższego kalibru. Zbezczeszczenie rasy (Rassenschande) oznaczało w praktyce prawnej Trzeciej Rzeszy zdradę wspólnoty narodowej i należało je karać bardzo surowo. W ówczesnej codzienności oznaczało to, że każdy "stosunek płciowy z osobami pochodzenia innego niż germańskie bądź innego koloru skóry"38 będzie karany w stopniu nieporównywalnie wysokim do przewinienia.

38 Por. J. Graf, Vererbungslehre, Rassenkunde, op. cit., s. 226. 
Stanisława Zasadę usiłowano ratować na wszelkie sposoby, kierując prośby do sądu okręgowego we Fryburgu Bryzgowijskim. Starania te nie przyniosły żadnego efektu. Gdy decyzja ostatecznie zapadła, miejscowi przedstawiciele władzy nazistowskiej zorganizowali szybki pokazowy proces, a egzekucję przewidziano $\mathrm{w}$ pobliskich kamieniołomach. Tego typu działania miały na celu odstraszenie zarówno robotników od kontaktów z Niemcami, jak i odwrotnie. Stanisława Zasadę czekała śmierć przez powieszenie; wyrok wykonać miał jeden z jego współziomków. Ciało miało zostać przekazane do prosektorium uniwersyteckiego we Fryburgu, potem zaś pochowane na cmentarzu żydowskim.

Paulina Kropf została osadzona najpierw w więzieniu okręgowym, potem odesłana do obozu koncentracyjnego w Ravensbrück, gdzie odsiadywała wyrok wieloletniego więzienia. Przygotowaną z wielką starannością egzekucję Stanisława Zasady przeprowadzono 16 października 1941 roku przy udziale większości mieszkańców Brombach.

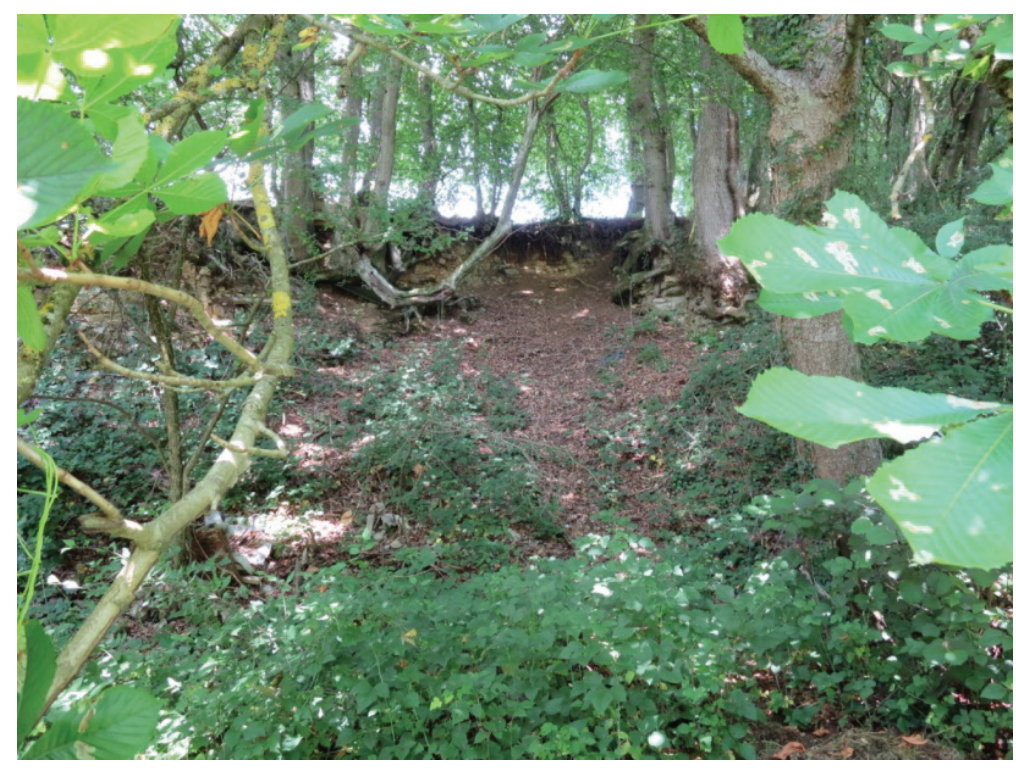

Rys. 3. Las, w którym dokonano egzekucji Stanisława Zasady (fot. Yves Jaenisch)

Nikomu nie przyszło do głowy, by sprzeciwić się temu, co zaszło; trzymano się litery prawa, prawa zabójców i morderców. Egzekucję zaplanowano na godzinę 7:45. Wszyscy zatrudnieni w powiecie Polacy mieli się stawić na miejscu stracenia - zarządzenie potwierdzają podpisy większości wójtów 
z wsi wokół Lörrach ${ }^{39}$. Niektórzy mieszkańcy wspominają dziś, że Polacy, z którymi mieli wówczas do czynienia, wrócili zastraszeni do miejsca zakwaterowania, a tajna policja urządziła w eleganckim i popularnym lokalu w Steinen przyjęcie $\mathrm{z}$ tej okazji ${ }^{40}$.

Zachowane w Lörrach i pobliskim Steinen dokumenty ukazują, jaką rolę miało odegrać powieszenie na szubienicy młodego Polaka. $Z$ jednej strony stanowiło to wymiar kary - odpowiedniej, zdaniem nazistów, do popełnionego czynu, z drugiej zaś miało uświadomić Niemcom, że muszą się oddzielać od wrogów - a takimi byli zatrudnieni wśród nich obcokrajowcy. W lipcu 1941 roku pojawiły się w Lörrach pogłoski, że niektóre kobiety zadają się z jeńcami wojennymi. Już wtedy Gestapo wprowadziło zarządzenie, którego trzymano się niekonsekwentnie, także po straceniu Stanisława Zasady: robotników przymusowych nie powinno się kwaterować indywidualnie, lecz zbiorowo, z dala od miejsca zatrudnienia ${ }^{41}$.

Badając losy robotników przymusowych z Polski i Rosji, Mechtild Brand stwierdziła, że „istnieje w Niemczech sporo mitów na temat pracy przymusowej w okresie Trzeciej Rzeszy. Uważa się ją za łagodniejszą formę doświadczenia nazizmu. Rzadko się zauważa sytuację wyobcowania i samotności, na jaką byli narażeni ludzie, zatrudniani u «normalnych» Niemców" ${ }^{\prime 2}$. Normalni i porządni Niemcy dokonali egzekucji Stanisława Zasady i uważali, że czynią to w zgodzie z wymaganiami "Volksgemeinschaft”, nie czując się zupełnie winnymi - uznali bowiem, że takie było prawo.

\section{Od doświadczenia do upamiętniania - obecność historii Pauliny i Stanisława w pamięci historycznej}

Nie, nikt nie chce znać prawdy, z wyjątkiem może nieznanych mi rodziców Polaka o ile jeszcze żyją - którzy przed wojną posiadali w Łodzi warsztat naprawy samochodów. Władze Badenii-Wirtembergii najmniej są zainteresowane, aby aresztować mieszkających i utrzymujących się z emerytur morderców tego - i licznych innych - jeńców, którzy z tego samego "powodu” zostali po partacku powieszeni, to znaczy - uduszeni. Przecież były premier tego kraju związ-

${ }^{39}$ H. Noe, Hingeschaut, op. cit, s. 143.

${ }^{40}$ Ibidem, s. 145

${ }^{41}$ Ibidem, s. 142.

${ }^{42}$ Cyt. za: M. Brand, Verschleppt und Entwurzelt. Zwangsarbeit zwischen Soest, Werl, Wickede und Möhnetal, Essen 2010, s. 11. 
kowego, dr Filbinger, był na tyle okrutny, że jeszcze w brytyjskiej niewoli, po śmierci Hitlera, prześladował niemieckich marynarzy w oparciu o nazistowskie ustawy ${ }^{43}$.

Pisarstwo Rolfa Hochhutha ${ }^{44}$ (urodzonego 1 kwietnia 1931 roku) nie pozostawia obojętnym. Nazywany jest on głównym moralistą powojennych Niemiec Zachodnich. Najbardziej znane jego dzieło, dramat Namiestnik (Stellvertreter) z 1963 roku, dało „początek całej serii utworów dokumentujących wydarzenia i moralne konstelacje dziejów najnowszych, które odmieniły krajobraz literacki Niemiec" 45 . Literatura stała się miejscem głębokich debat i kontrowersji, które bezpośrednio wpływały na ówczesną rzeczywistość.

Znamienity tygodnik "Die Zeit” opublikował w wydaniu z 17 lutego 1978 roku fragmenty powieści dokumentalnej Eine Liebe in Deutschland Hochhuta. Książka ta, oparta w całości na historii tragicznej miłości Pauliny Kropf i Stanisława Zasady, zawierała otwarte oskarżenia wobec premiera kraju związkowego Badenii-Wirtembergii - Hansa Filbingera (1913-2007), którego praktyki sędziowskie doprowadziły w swych skutkach, zdaniem autora, do takiego prawodawstwa, jakie reprezentowali i wcielali $\mathrm{w}$ życie naziści. W Niemczech wybuchł ogromny skandal, w którym ostatecznie racja znalazła się po stronie pisarza. Dokumenty archiwalne były jednoznaczne - Filbingerowi udowodniono, że w latach 1943-1945, także w okresie po śmierci Hitlera, a przed kapitulacją Niemiec, skazał na śmierć dezerterów z niemieckiej marynarki wojennej. Ukrywał on swoje zachowanie, a nawet, mimo protestów, jakie wywołała powieść o Stanisławie i Paulinie, obstawał przy "sprawiedliwości” nazistowskiego państwa. W rezultacie afery politycznej premier Badenii-Wirtembergii ustąpił późną jesienią 1978 roku.

Niemiecka opinia publiczna zapoznała się z historią miłości tych dwojga, podjęto próbę debaty, skupiając się raczej na oprawcach niż ofiarach. Sam autor ukazał Stanisława Zasadę jako tego, który „w jednej osobie ucieleśnia tutaj wszystkich bezimiennych Polaków, którzy w Niemczech przeżyli i przecierpieli swój los"46. Recenzenci książki Hochhuta zarzucali jej nadmierną dokumentarność, odniesienia do konkretnych ustaw, a wręcz historii idei, które w konsekwencji doprowadziły do tego, że "powiatowe miasteczko oszalało". Dla wielu przeciętnych Niemców książki tego autora stanowiły

\footnotetext{
${ }^{43}$ R. Hochhuth, op. cit., s. 53.

${ }^{44}$ Biogram tego pisarza zawiera publikacja: Pisarze Niemieckojęzyczni XX w. Leksykon Encyklopedyczny PWN, red. M. Zybura, Warszawa -Wrocław 1996, s. 136-137.

${ }^{45}$ Zygmunt Światłowski, hasło: „Rolf Hochhuth”, [w:] ibidem, s. 136.

${ }^{46}$ R. Hochhuth, Mitość w Niemczech, op. cit., s. 53.
} 
(i stanowią) często prowokację - mającą z perspektywy badań nad pamięcią wybitnie katartyczny charakter.

Niestety, w filmie Andrzeja Wajdy Eine Liebe in Deutschland (1983), opartym na motywach powieści Rolfa Hochhutha, nie udało się zachować tej historii na tyle, aby się na trwałe zapisała w pamięci zbiorowej Niemców. Temat, choć bardzo "rozliczeniowy”, pozostał płytkim melodramatem, a pikanterii dodawał fakt, że główne zdjęcia wykonano w Berlinie Zachodnim, gdyż mieszkańcy Brombach nie zgodzili się wówczas na kręcenie filmu o zajściach z 1941 roku - po aferze i ustąpieniu Filbingera nie byli jeszcze gotowi na przyjęcie gorzkiej prawdy.

Badania nad historią południowej Badenii w okresie nazistowskim rozpoczęły się na dobre dopiero w latach dziewięćdziesiątych ubiegłego stulecia i trwają do dziś. W 2010 roku rada dzielnicy Lörrach-Brombach przyjęła jednogłośnie decyzję o ufundowaniu kamienia pamięci poświęconego Stanisławowi Zasadzie.

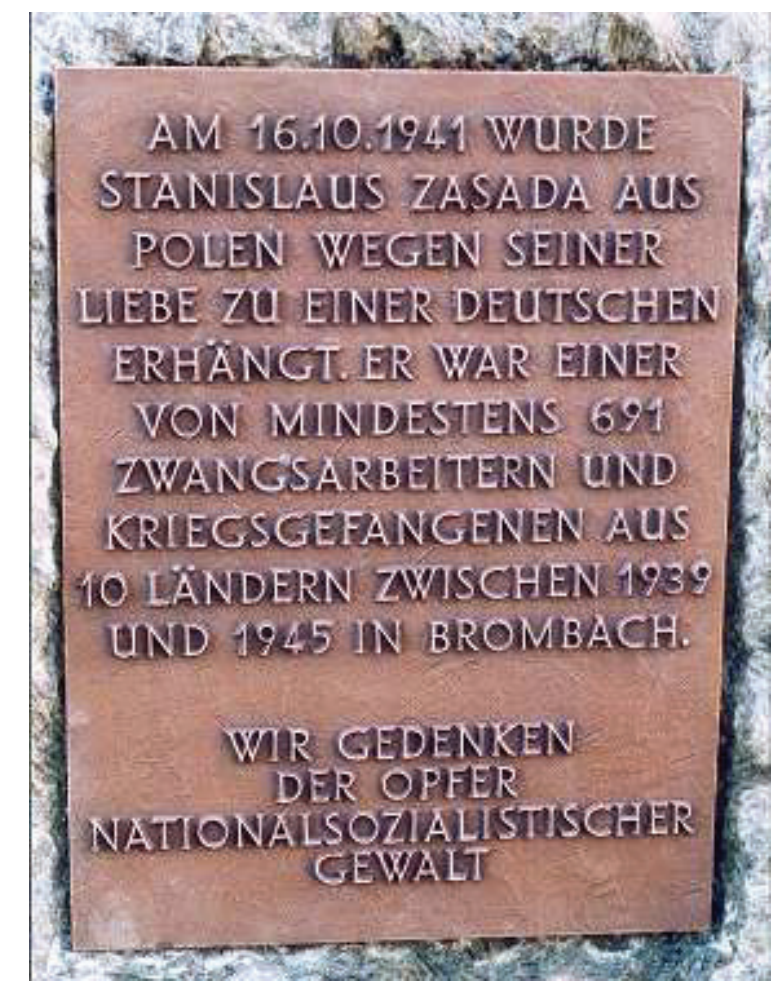

Rys 4. Tablica pamiątkowa umieszczona na obelisku pochodzącym z kamieniołomu, gdzie powieszono Stanisława Zasadę (fot. Yves Jaenisch) 
Po wielu latach ludzie opowiadają tę historię na nowo: przy okazji promocji książki poświęconej powiatowi Lörrach w latach 1933-1945 przypomniano jeszcze inne miłości tamtego czasu ${ }^{47}$. Nie wszystkie skończyły się tak tragicznie, jak los tych dwojga, Niemki i Polaka, opisany w książce Rochhutha.

Józef Janus, robotnik przymusowy ze Spytkowic, pracował od 1944 na gospodarstwie w Schillinghof. Jego niemiecki pracodawca ukrywał cały czas miłość swojej córki do Polaka, bojąc się nieustannie denuncjacji ze strony sąsiadów. Młodzi zdecydowali się jednak na ucieczkę zimą 1945 roku i udali się na francuską stronę Renu (za Weil am Rhein), a tam udało im się doczekać kapitulacji Trzeciej Rzeszy. Dziś ich potomkowie gospodarują na ojcowiźnie nieopodal powiatowego miasteczka na niemiecko-szwajcarskim pograniczu, a dzieje zbiorowej choroby zwanej Volksgemeinschaft powinny wypełniać annały historii.

\section{Trapped by Volksgemeinschaft. Polish-German relation on love and loneliness in the Third Reich}

Summary

The paper presents development of the Third Reich as a Volksgemeinschaft on the example of Lörrach, a small town at the Swiss- German border. In the context of world war II the authoress writes about the fate of forced labour workers, especially those from Poland. On the basis of analysis of documents and literary reports, a history of love between a Polish man and a German woman, which ended with sentencing the young man to death, was reconstructed. The problem of having to face and accept the Nazi past by German society is also touched.

47 Por. „Margräfler Tagblatt“, nr 124 z 31 maja 2014 r. 